\title{
RAZPRAVE
}

\section{GEOGRAFSKA ANALIZA VOLILNE UDELEŽBE V SLOVENIJI}

\author{
AVTORJA \\ dr. Boštjan Rogelj \\ Univerza v Ljubljani, Filozofska fakulteta, Oddelek za geografijo, Aškerčeva cesta 2, SI - 1000 Ljubljana, \\ Slovenija \\ bostjan.rogelj@ff.uni-lj.si
}

\section{Jernej Tiran}

Znanstvenoraziskovalni center Slovenske akademije znanosti in umetnosti, Geografski inštitut Antona Melika, Gosposka ulica 13, SI - 1000 Ljubljana, Slovenija

jernej.tiran@zrc-sazu.si

DOI: $10.3986 / G V 86202$

UDK: 91:342.843(497.4)

COBISS: 1.01

\section{IZVLEČEK}

\section{Geografska analiza volilne udeležbe $v$ Sloveniji}

$V$ prispevku je predstavljena geografska analiza volilne udeležbe na volitvah v Državni zbor Republike Slovenije v obdobju 1992-2014. S prostorsko-ekološkim pristopom in uporabo različnih multivariatnih statističnih metod smo skušali razkriti prostorsko strukturo volilne udeležbe in ugotoviti njene najpomembnejše dejavnike. Ugotovili smo, da se prostorske razlike v volilni udeležbi v času niso povečale, se je pa nekoliko spremenila prostorska struktura udeležbe, saj je polarizacijo vzhod-zahod iz devetdesetih let prejšnjega stoletja vzadnjem desetletju zamenjala polarizacija med osrednjo in preostalo Slovenijo. Višja volilna udeležba je na splošno značilna za okraje z boljšo izobrazbeno sestavo in nižjima deležema brezposelnosti ter ostalih neaktivnih prebivalcev.

\section{KLJUČNE BESEDE}

volitve, volilna udeležba, volilna geografija, dejavniki volilnega vedenja, Slovenija

\section{ABSTRACT}

\section{Geographical analysis of voter turnout in Slovenia}

The article presents the geographical analysis of the voter turnout in the Slovenian parliamentary elections between 1992 and 2014. A spatial-ecological approach was used along with various multivariate statistical methods to determine the spatial structure or the voter turnout and ascertain its most important factors. The results show that the spatial differences in the voter turnout have not increased with time; however, the spatial structure of the turnout had changed somewhat: this is because the east-west polarization from the 1990s shifted in the past decade towards a polarization between central Slovenia and the rest of the country. A higher voter turnout is generally characteristic for districts with a superior educational structure and a lower share of unemployment and other inactive inhabitants.

\section{KEY WORDS}

elections, voter turnout, electoral geography, factors of electoral behaviour, Slovenia

Uredništvo je prispevek prejelo 2. oktobra 2014. 


\section{Uvod}

Leto 2014 je v Sloveniji zaznamovalo pestro politično dogajanje. Razprtijam v največji vladni stranki sta sledila odstop predsednice vlade in razpustitev Državnega zbora, zaradi česar so bile 13. julija izvedene že druge predčasne parlamentarne volitve $\mathrm{v}$ zadnjih treh letih. Zaradi neobičajnega datuma volitev, ki je bil v času poletnih dopustov in šolskih počitnic, smo spremljali burno javno razpravo glede omejevanja možnosti uresničevanja volilne pravice, kar naj bi negativno vplivalo na volilno udeležbo ter reprezentativnost volilnega telesa in tako pod vprašaj postavilo legitimnost volitev. Proti nekaterim drugačnim napovedim, se je volitev udeležila več kot polovica volilnih upravičencev, a je bila volilna udeležba z 51,7\% najnižja na državnozborskih volitvah doslej.

Zanimivo je, da v Sloveniji še ni bila opravljena empirična raziskava dejavnikov volilne (ne)udeležbe, čeprav je ta pogosto predmet številnih političnih razprav, še posebej v pred- in povolilnem času (Medmrežje 1-3). V okviru teh razprav so se pojavile tudi različne teze o regionalnih razlikah v volilni udeležbi in razlogih zanjo. Vprašanje, ali je v teh tezah tudi kaj resnice, terja poglobljeno, širšo in prostorsko naravnano analizo. V kolikor obstajajo območja z nizko udeležbo znotraj države, lahko odražajo določeno mero izključenosti teh območij iz nacionalne politike ali pa obliko protestnega vedenja (Kropivnik 1998, 44), zato je poznavanje prostorskih razlik v udeležbi in dejavnikov zanje še kako pomembno.

Volilna udeležba (participacija) je nasprotna volilni neudeležbi (abstinenci) in jo opredelimo z odstotkom volilnih upravičencev, ki se udeležijo volitev, ne glede na to, ali na njih oddajo veljavno glasovnico ali ne. Udeležba državljanov na volitvah je eden glavnih pokazateljev stabilnosti demokracije (Fink-Hafner 1993) in družbene anomije (Brezovšek 2002). V novejšem obdobju sta v ospredju raziskav volilne udeležbe predvsem dve vprašanji: zakaj imamo v sodobnih družbah opravka s čedalje večjo volilno abstinenco ter politično pasivnostjo (Wattenberg 2002; Le Duc in Pamett 2003; Kropivnik in Vrhovac 2012; Delwit 2013) in kateri so tisti dejavniki, ki najbolj vplivajo na volilno (ne)udeležbo (Sigelman s sodelavci 1985; Pattie in Johnston 1998; Blais 2006; Wesley 2012).

Pričujoči prispevek predstavlja prvo bolj analitično prostorsko raziskavo volilne udeležbe na volitvah v Državni zbor Republike Slovenije. V prispevku želimo odgovoriti na dve vprašanji, ali v Sloveniji obstajajo bistvene prostorske razlike v volilni udeležbi ter kateri demografski in družbenogospodarski dejavniki imajo največji vpliv na volilno udeležbo v Sloveniji. $\mathrm{V}$ prvem delu analize so tako predstavljene ključne značilnosti, prostorska struktura in trendi volilne udeležbe, $\mathrm{v}$ drugem delu pa njeni najpomembnejši dejavniki.

\section{Metodologija}

V raziskavi smo sledili »prostorsko-ekološkemu « pristopu, ki sicer skuša razkriti ključne dejavnike volilne udeležbe, a se pri razlagi v glavnem osredotoča na vpliv značilnosti prostora, ki na posameznika delujejo v smeri poenotenja stališč in volilnovedenjskih vzorcev. Agregiranih podatkov zaradi nevarnosti tako imenovane ekološke napake nismo uporabili za oblikovanje sklepov o značilnostih posameznih (ne)volivcev, pač pa smo, podobno kot nekatere druge raziskave (Cox 1968; Agnew 1987; Wesley 2012), obravnavali volilni proces kot »skupinsko doživetje«, ki ni odvisen le od individualne izbire.

Za prostorsko enoto preučevanja smo izbrali volilne okraje. Volilni okraji so se namreč izkazali za najmanjšo prostorsko enoto, za katero so dostopni tako podatki o volilni udeležbi kot različni demografski in družbenogospodarski kazalniki, s katerimi smo skušali pojasniti razlike v udeležbi. Z vsebinskega vidika bi bilo sicer bolje, če bi analizo izvedli na manjših prostorskih enotah, kot so na primer volišča, naselja ali občine, a nekateri kazalniki na teh ravneh niso bili dostopni, obenem pa se podatki o drugih

Slika 1: Volilni okraji v Sloveniji. 


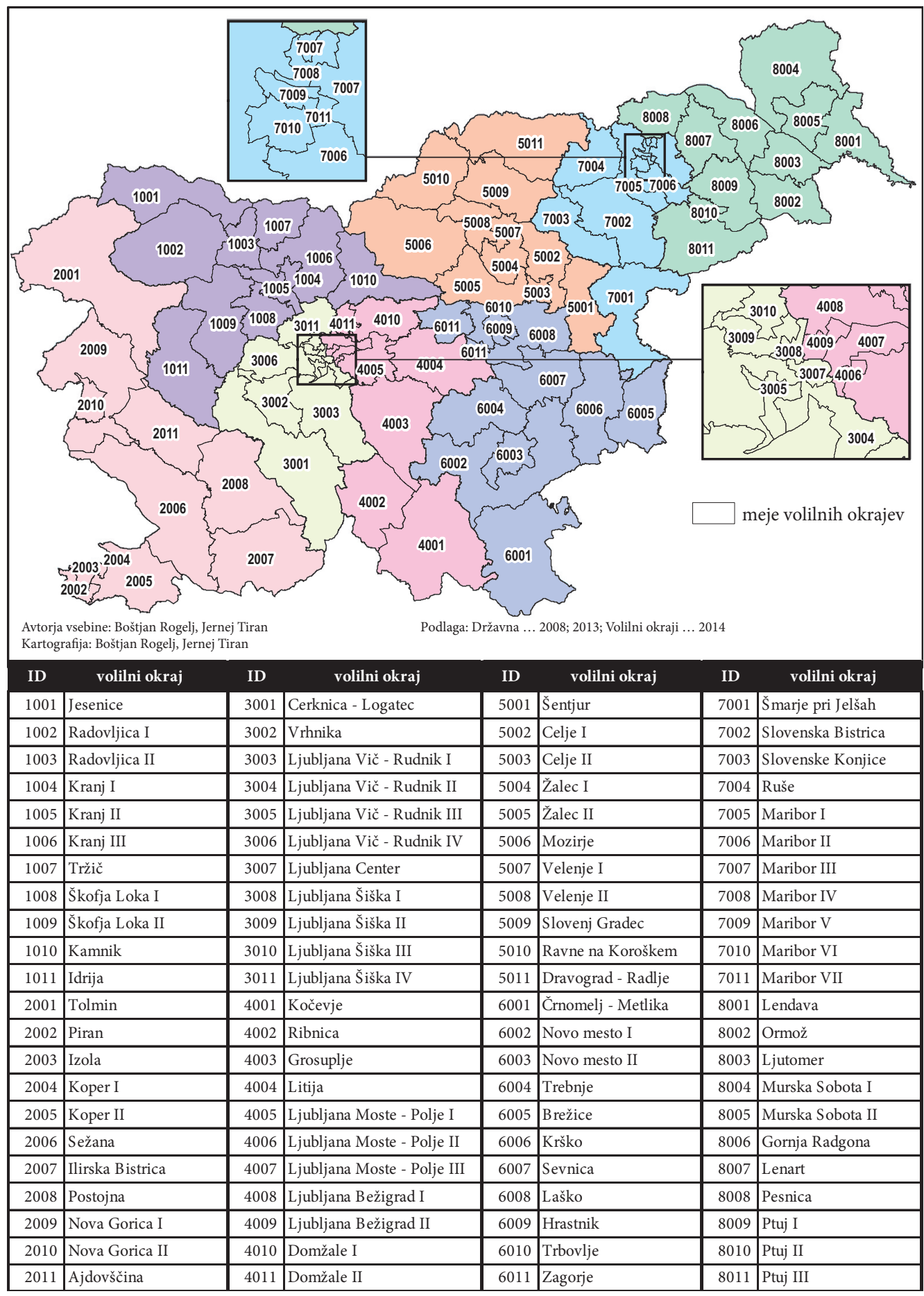


oblikah glasovanja (predčasno glasovanje, glasovanje iz tujine, po pošti, na domu in zunaj okraja stalnega prebivališča) zbirajo zgolj na ravni volilnih okrajev. V analizo smo vključili podatke o volilni udeležbi po volilnih okrajih na vseh sedmih državnozborskih volitvah med letoma 1992 in 2014 (redne volitve leta 1992, 1996, 2000, 2004 in 2008 ter predčasne volitve leta 2011 in 2014 (Statistični letopis ... 1992; Volilna statistika ... 1996; Državnozborske volitve ... 2000; 2004; Volitve ... 2008; Predčasne volitve ... 2011; 2014)). Meje okrajev se v tem času niso bistveno spremenile, izjemi sta le oba novomeška in oba škofjeloška okraja (slika 1; Rogelj 2012).

V prvem delu analize smo predstavili najpomembnejše značilnosti volilne udeležbe $v$ preučevanem obdobju. Nato smo s pomočjo dvostopenjskega hierarhičnega razvrščanja izdelali dve razvrstitvi v skupine. Prva razvrstitev je bila narejena na podlagi volilne udeležbe v obdobju 1992-2000, druga na podlagi udeležbe v obdobju 2004-2014. Delitev na dve obdobji se nam je zdela smiselna, saj sta bila za prvo obdobje značilna zelo visoka udeležba in proces utrjevanja strankarskega prostora (krepitev »tradicionalnih strank«), za drugo pa nekoliko nižja udeležba in proces drobljenja strankarskega prostora.

$\mathrm{V}$ drugem delu analize smo preučili vpliv demografske in družbenogospodarske sestave volilnega telesa na volilno udeležbo 2011 in 2014. V analizo smo vključili podatke o starostni in izobrazbeni sestavi, zaposlenih oziroma brezposelnih ter zaposlenosti po sektorju dejavnosti (Državljani Republike ... 2011; 2012a; 2012b; 2012c; 2012d; 2013a; 2013b; 2014a; 2014b; Predčasne volitve ... 2011; 2014; Zaposleni državljani ... 2012; 2013). Zaradi nedostopnosti podatkov o dohodkih ter verski pripadnosti državljanov na ravni volilnih okrajev teh povezav nismo mogli preveriti. Smo pa v analizo vključili delež prebivalcev s prvim prebivališčem v Sloveniji/tujini in delež priseljenih, saj smo želeli preveriti domnevo o mobilizaciji »novih državljanov« na volitvah 2011 (Medmrežje 2). Podatki veljajo za državljane Republike Slovenije, starejše od 18 let s stalnim prebivališčem v Republiki Sloveniji, kar je statistična kategorija, ki je najboljši približek kategoriji volilnih upravičencev. Na podlagi omenjenih podatkov smo skupaj oblikovali 44 spremenljivk.

S korelacijsko analizo smo najprej pridobili osnovno sliko o povezanosti med demografskimi in družbenogospodarskimi kazalniki in udeležbo na volitvah 2011 in 2014 ter iz nadaljnjih analiz izločili vse spremenljivke, pri katerih je bila povezanost statistično nepomembna. Nato smo preverili, kako so dobljeni rezultati povezani $\mathrm{z}$ rezultati metode razvrščanja $\mathrm{v}$ skupine. Zanimalo nas je, ali se štiri skupine na podlagi podatkov o volilni udeležbi med letoma 2004 in 2014 med seboj razlikujejo po vrednostih izbranih kazalnikov. $\mathrm{V}$ ta namen smo izvedli enosmerno analizo variance, s post-hoc testiranjem pa tudi primerjave med posameznimi pari skupin. Na koncu smo izvedli še multiplo linearno regresijsko analizo in izdelali dva modela (za volitve 2011 in 2014), s katerima smo na podlagi izbranih kazalnikov napovedovali volilno udeležbo. Modela smo izdelali s pomočjo metode postopnega vključevanja (Stepwise metoda).

\section{Izbrane značilnosti volilne udeležbe}

Za Slovenijo je, tako kot za večino drugih držav (Niemi in Weisberg 2001; Delwit 2013), značilen trend padanja volilne udeležbe. Udeležba je v obdobju 1992-2004 stalno padala (najbolj izrazito na volitvah 1996 in 2004), med letoma 2008 in 2011 je nekoliko narasla, na volitvah 2014 pa se je ponovno zmanjšala in je bila z 51,7 \% najnižja doslej. Vse do volitev 2014 v nobenem volilnem okraju udeležba ni bila manjša od 50 \%, kar na splošno velja za »kritično mejo « legitimnosti volitev (Koprivnik 1998). Kako visoko stopnjo politične participacije je imela Slovenija leta 1992, ponazarja tudi podatek, da je bila takrat najmanjša udeležba v katerem od okrajev 75,2 \%, kar je več od povprečne udeležbe na vseh naslednjih volitvah in več od najvišje udeležbe v katerem od okrajev od volitev 2004 naprej (preglednica 1, slika 2).

Zanimalo nas je, ali se razlike v volilni udeležbi med volilnimi okraji povečujejo v času. To nam najbolje ponazori primerjava koeficientov variacije, ki pomeni, koliko odstotkov povprečja znaša stan- 
dardni odklon. Koeficient variacije je bil s 5,3 \% najmanjši na volitvah 1992, ko so bile razlike med okraji doslej najmanjše, in največji na volitvah 2014, ko so bile razlike med okraji z 8,8 \% doslej največje, a ne bistveno večje v primerjavi s prejšnjimi volitvami. Ugotovimo lahko, da se volilna udeležba v posameznih okrajih v preučevanem obdobju ni zelo razlikovala od povprečne udeležbe oziroma razlike med okraji niso bile zelo velike (preglednica 1). Stabilnost prostorskih razlik v udeležbi v času oziroma njeno precej enakomerno zmanjševanje na območju cele države potrjujejo tudi visoke vrednosti Pearsonovega korelacijskega koeficienta med pari volitev (preglednica 2).

Preglednica 1: Izbrane značilnosti volilne udeležbe na volitvah v Državni zbor 1992-2014 (Statistični letopis ... 1992; Volilna statistika ... 1996; Državnozborske volitve ... 2000; 2004; Volitve ... 2008;

Predčasne volitve... 2011; 2014).

\begin{tabular}{lccccccc}
\hline & $\mathbf{1 9 9 2}$ & $\mathbf{1 9 9 6}$ & $\mathbf{2 0 0 0}$ & $\mathbf{2 0 0 4}$ & $\mathbf{2 0 0 8}$ & $\mathbf{2 0 1 1}$ & $\mathbf{2 0 1 4}$ \\
\hline $\begin{array}{l}\text { volilna udeležba na državni ravni } \\
\text { udeležba v volilnem okraju z najvišjo udeležbo }\end{array}$ & $\mathbf{8 5 , 8}$ & $\mathbf{7 3 , 7}$ & 70,4 & 60,7 & 63,1 & 65,6 & 51,7 \\
$\begin{array}{l}\text { udeležba v volilnem okraju z najnižjo udeležbo } \\
\text { razlika med volilnim okrajem z najvišjo }\end{array}$ & 75,2 & 57,6 & 80,1 & 70,6 & 72,3 & 74,7 & 60,1 \\
$\begin{array}{l}\text { in najnižjo udeležbo } \\
\text { koeficient variacije }\end{array}$ & 16,8 & 27,0 & 23,7 & 20,4 & 21,6 & 22,5 & 21,7 \\
$\begin{array}{l}\text { koeficient asimetrije } \\
\text { koeficient sploščenosti }\end{array}$ & 5,3 & 8,6 & 7,9 & 8,2 & 8,0 & 7,7 & 8,8 \\
\hline
\end{tabular}

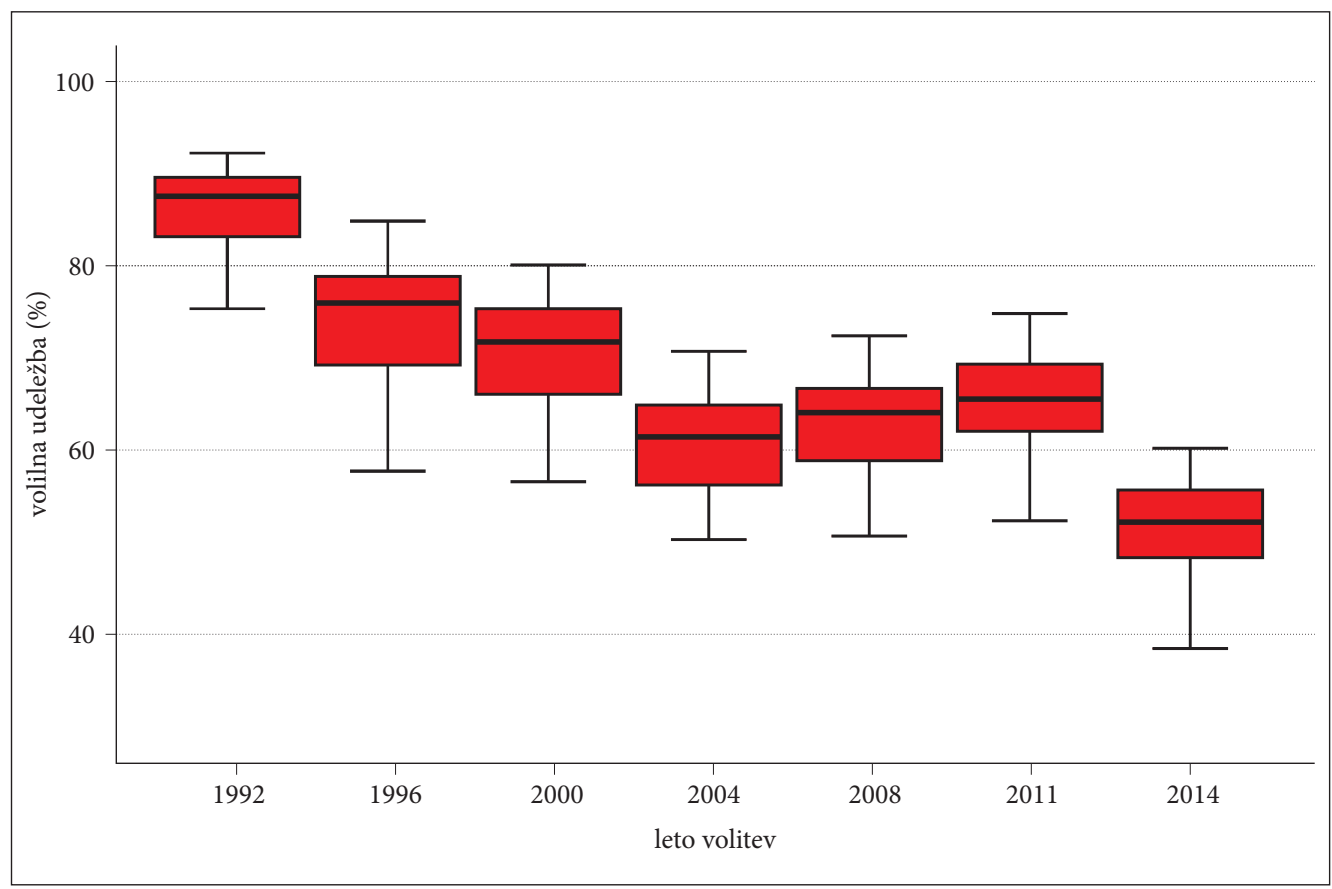

Slika 2: Kvantilni diagram volilne udeležbe 1992-2014 (Statistični letopis ... 1992; Volilna statistika ... 1996; Državnozborske volitve ... 2000; 2004; Volitve ... 2008; Predčasne volitve ... 2011; 2014). 
Koeficienti asimetrije in sploščenosti (preglednica 1) razkrivajo rahlo asimetričnost v levo, kar pomeni, da je leva stran frekvenčne porazdelitve nekoliko razpotegnjena, in sploščenost porazdelitev, ki torej nimajo izrazitega vrha, ampak se vrednosti pršijo okrog aritmetične sredine. Vrednosti koeficientov se med volitvami sicer nekoliko razlikujejo (porazdelitev je bila najbolj asimetrična v levo na volitvah 1992, najbolj sploščena pa na volitvah 2000). Ti dve lastnosti sta razvidni tudi iz kvantilnega diagrama na sliki 1 (rdeči štirikotnik ponazarja vrednosti v območju 2. in 3. kvartila, odebeljena črta pa mediano).

Preglednica 2: Pearsonovi korelacijski koeficienti med pari volitev.

\begin{tabular}{clllllll}
\hline volitve v Državni zbor & $\mathbf{1 9 9 2}$ & $\mathbf{1 9 9 6}$ & $\mathbf{2 0 0 0}$ & $\mathbf{2 0 0 4}$ & $\mathbf{2 0 0 8}$ & $\mathbf{2 0 1 1}$ & $\mathbf{2 0 1 4}$ \\
\hline $\mathbf{1 9 9 2}$ & 1 & & & & & & \\
$\mathbf{1 9 9 6}$ & 0,92 & 1 & & & & & \\
$\mathbf{2 0 0 0}$ & 0,86 & 0,93 & 1 & & & & \\
$\mathbf{2 0 0 4}$ & 0,71 & 0,82 & 0,89 & 1 & & & \\
$\mathbf{2 0 0 8}$ & 0,67 & 0,74 & 0,84 & 0,89 & 1 & & \\
$\mathbf{2 0 1 1}$ & 0,67 & 0,73 & 0,80 & 0,83 & 0,94 & 1 & \\
$\mathbf{2 0 1 4}$ & 0,62 & 0,68 & 0,78 & 0,87 & 0,95 & 0,92 & 1 \\
\hline
\end{tabular}

\section{Prostorska struktura volilne udeležbe}

V postopku dvostopenjskega hierarhičnega razvrščanja volilnih okrajev v skupine se je izkazalo, da je najprimernejša delitev na štiri skupine (na okraje z močno podpovprečno, podpovprečno, nadpovprečno in močno nadpovprečno volilno udeležbo), saj so se ostale delitve zaradi prevelikih razlik v velikosti posameznih skupin izkazale kot neprimerne za nadaljnje analize.

Za obdobje 1992-2000 je značilna precej izrazita prostorska polarizacija vzhod-zahod. Vzhodni del je imel nižjo, zahodni pa višjo volilno udeležbo od povprečja (slika 3). Močno nadpovprečna udeležba je bila značilna za Notranjsko, vzpeti del zahodne Slovenije, večino okrajev v širšem zaledju Ljubljane, večji del Gorenjske in Zgornjega Posočja, močno podpovprečna pa je bila v širši okolici Maribora, v Posavju in na južnem Štajerskem ob meji s Hrvaško ter v okrajih Lendava in Piran. Izmed okrajev, ki jih običajno uvrščamo med "vzhodne«, so imeli nadpovprečno udeležbo okraji v jugovzhodni Sloveniji, Zasavju in zahodnem delu Savinjske regije. Zahodni in vzhodni del države sta bila po udeležbi dokaj homogena. V tem pogledu so bili na zahodu države izjema le vsi štirje volilni okraji v slovenski Istri (Izola, Koper I in II ter Piran) in okraj Jesenice, v osrednji Sloveniji pa okraj Ljubljana Moste-Polje II, medtem ko na vzhodu ni bilo večjih odstopanj. Območji z (močno) nadpovprečno in podpovprečno udeležbo sta bili tako dokaj sklenjeni. Podobno je s primerjavo udeležbe na volitvah v Družbenopolitični zbor leta 1990 in volitvah v Državni zbor 1992 ugotovil tudi Kropivnik (1998, 72-73), le razlike med obema območjema so bile nekoliko manjše.

V drugem obdobju (2004-2014) pa je polarizacijo med vzhodnim in zahodnim delom države zamenjala polarizacija med osrednjo in preostalo Slovenijo (slika 4). Volilna udeležba se je najbolj zmanjšala v treh južnoprimorskih okrajih - Ilirski Bistrici, Postojni in Sežani - kjer je bila udeležba v obdobju 1992-2000 višja od državnega povprečja. Podobno velja tudi za jugovzhodno Slovenijo oziroma območje Dolenjske, Bele Krajine in Kočevskega (volilni okraji Kočevje, Črnomelj - Metlika in Novo mesto I), kjer je bila prej nadpovprečna, ter za oba koprska okraja in okraj Jesenice, kjer je bila sicer že prej podpovprečna, zdaj pa se ti trije okraji uvrščajo med okraje z najnižjo, močno podpovprečno udeležbo. Ob tem je treba dodati, da območje močno nadpovprečne volilne udeležbe ni omejeno samo na Ljubljano in Osrednjeslovensko regijo (za tri ljubljanske volilne okraje na primer velja, da je v njih ude- 
ležba nadpovprečna, v enem pa celo podpovprečna), ampak je mnogo širše in obsega tudi predele Gorenjske, Notranjske in Dolenjske. Po drugi strani se nekateri okraji s prej podpovprečno udeležbo zdaj uvrščajo med okraje z nadpovprečno udeležbo (Murska Sobota I, Slovenj Gradec, Žalec I), udeležba v dobršnem delu vzhodne Slovenije (zlasti širšem zaledju Maribora) pa se ni zmanjševala močneje od državnega povprečja.

Spremembe v razvrstitvi okrajev v skupine ponazarja tudi zemljevid, ki prikazuje spremembo udeležbe v obdobju 1992-2000 v primerjavi z obdobjem 2004-2014 (slika 5). V območjih z indeksom pod 100 se je udeležba zmanjšala manj od državnega povprečja, v območjih z indeksom nad 100 pa bolj od državnega povprečja. Med območji, kjer se je udeležba najbolj zmanjšala, so: severna in južna Primorska skupaj z okrajem Postojna, jugovzhodna Slovenija, Zasavje, okraj Jesenice in skrajni del severovzhodne Slovenije. Še posebej je zanimiv okraj Ilirska Bistrica, kjer je bila na volitvah 1992 in 1996 četrta oziroma enajsta najvišja volilna udeležba v državi, a se je na volitvah 2000 od vseh okrajev najbolj zmanjšala in se od volitev 2008 »ustalila « med okraji z najnižjo udeležbo. Udeležba pa se je najmanj zmanjšala v večjem delu Podravja, na Koroškem, v obeh žalskih okrajih, pa tudi v večjem delu osrednje Slovenije. Pri tem je treba poudariti, da je udeležba v večjem delu Podravja kljub temu še vedno med nižjimi v državi.

Rezultate volilne udeležbe smo za volitve 2014 kartografsko prikazali tudi na ravni volišč (slika 6), s čimer smo želeli ugotoviti, kako velike so razlike v udeležbi znotraj posameznih volilnih okrajev, zlasti glede na stopnjo urbaniziranosti. Ob tem je treba dodati, da podatki o udeležbi na ravni volišč niso povsem točni; v izvirnih podatkih namreč niso všteti tisti volivci, ki so svoj glas oddali predčasno, po pošti, $\mathrm{v}$ tujini ali kako drugače. Rezultatom na ravni volišč smo zato prišteli delež glasov z drugih oblik

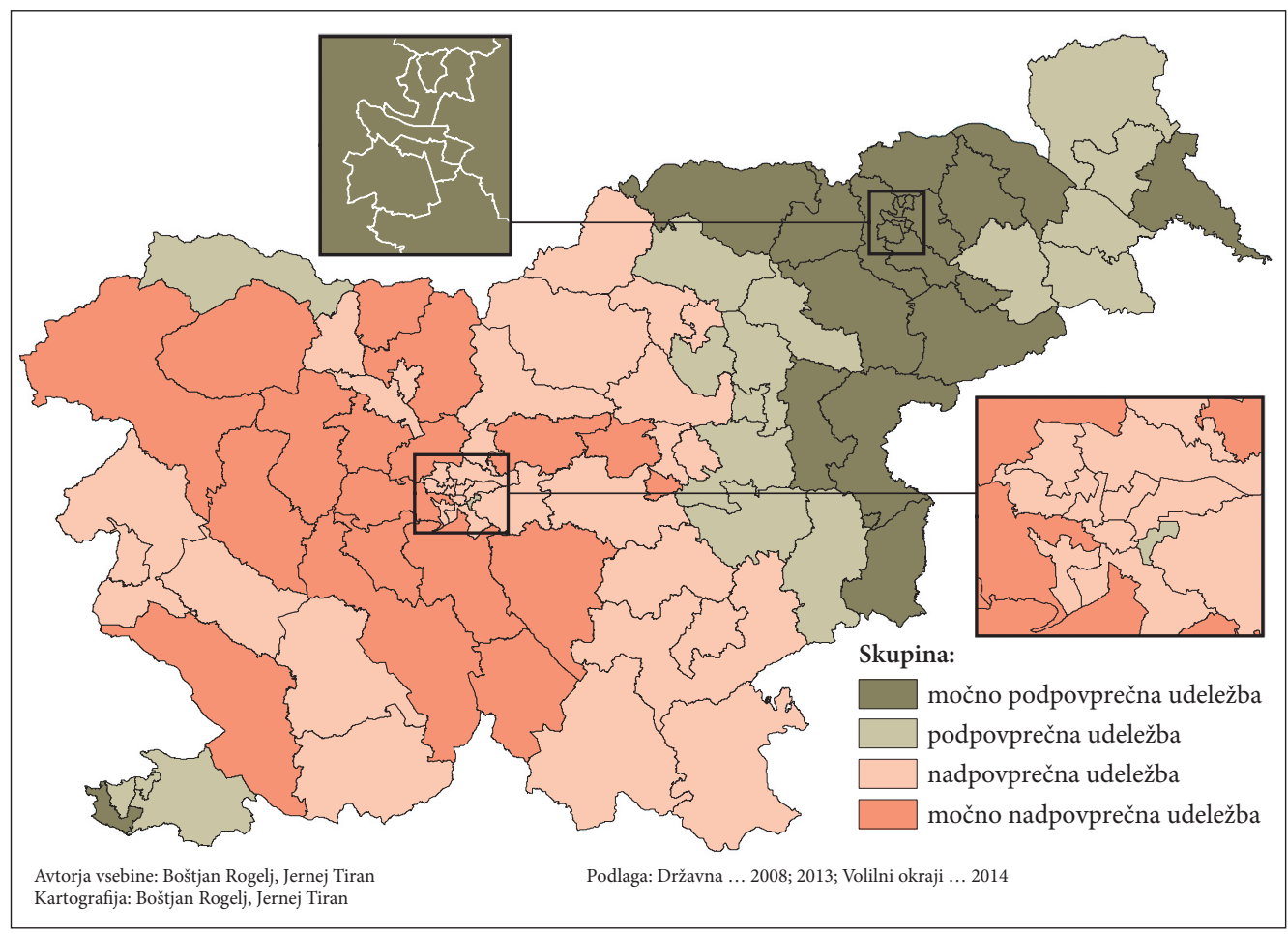

Slika 3: Razvrstitev volilnih okrajev v skupine po volilni udeležbi v obdobju 1992-2000 (viri za izračun: Statistični letopis ... 1992; Volilna statistika ... 1996; Državnozborske volitve ... 2000). 


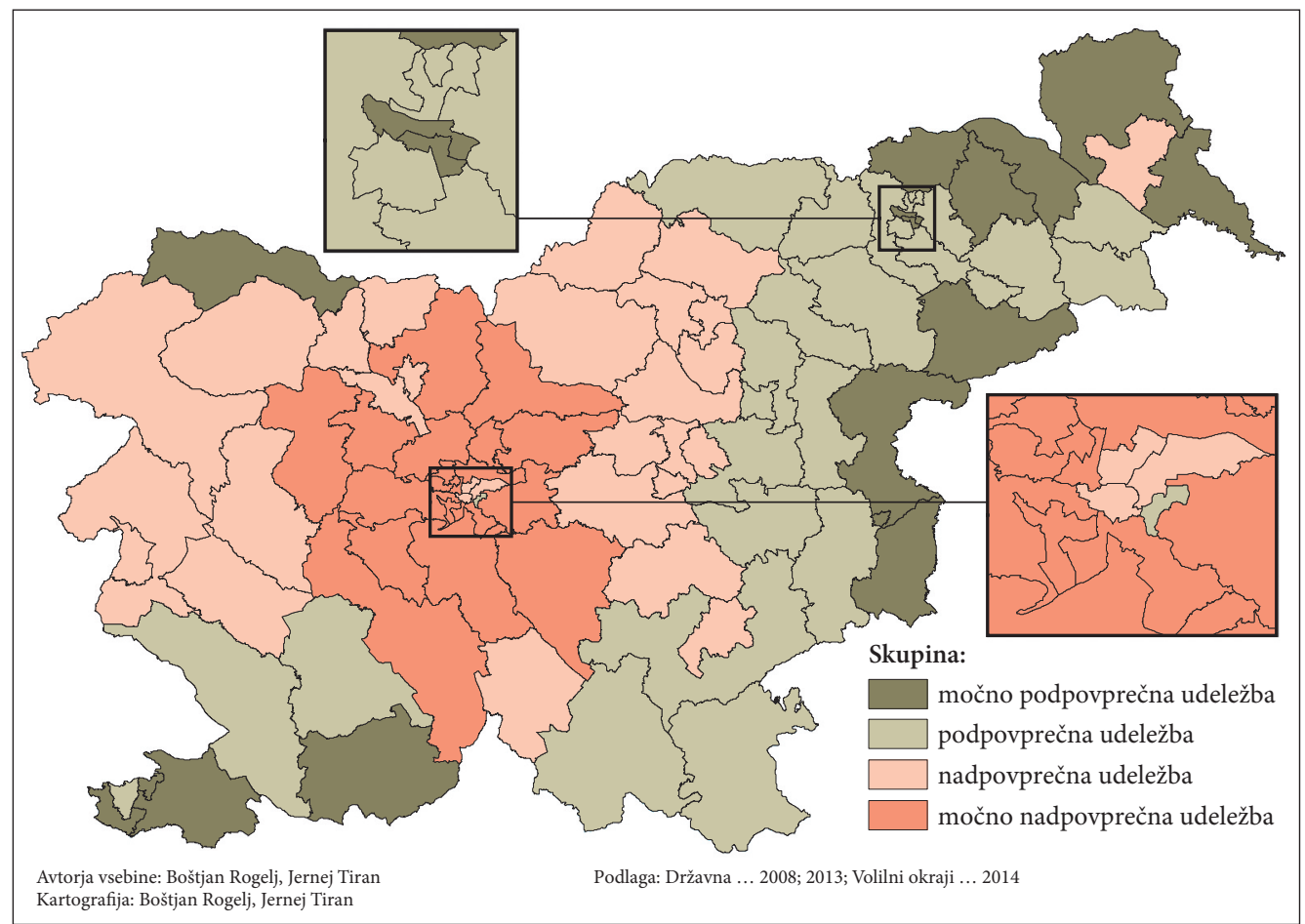

Slika 4: Razvrstitev volilnih okrajev v skupine po volilni udeležbi v obdobju 2004-2014 (viri za izračun: Državnozborske volitve 2004; Volitve ... 2008; Predčasne volitve ... 2011; 2014).

glasovanja, ki je na voljo le na ravni volilnih okrajev, ta delež pa se znotraj njih lahko razlikuje. Natančnejši vpogled v prostorsko strukturo udeležbe dokazuje, da imamo - v nasprotju od volilnih orientacij (Tiran 2011) - v večini okrajev opravka s precej homogeno udeležbo. Razen v primeru Novega mesta, kjer je udeležba višja $\mathrm{v}$ mestu kot $\mathrm{v}$ njegovi podeželski okolici, ni večjih razlik med mesti ter njihovimi obmestnimi in podeželskimi zaledji. Dokaj velike razlike pa se pojavljajo znotraj nekaterih (večjih) mest, še posebej v Ljubljani, kjer se prostorska struktura udeležbe navidezno precej ujema z družbenogeografsko sestavo (Rebernik 2013).

\section{Dejavniki volilne udeležbe}

Izračunani Pearsonovi korelacijski koeficienti $\left(\mathrm{r}_{\mathrm{xy}}\right)$ in determinacijski koeficienti $\left(\mathrm{r}_{\mathrm{xy}}{ }^{2}\right)$ med volilno udeležbo ter izbranimi demografskimi in družbenogospodarskimi kazalniki so prikazani v preglednici 3. Pri tem velja opozoriti, da iz teh rezultatov ni mogoče določiti vpliva še drugih spremenljivk oziroma kompleksne medsebojne povezanosti različnih kazalnikov.

Izkazalo se je, da sta najpomembnejša dejavnika udeležbe aktivnost in izobrazba, ki sta z udeležbo zmerno statistično povezana. $V$ volilnih okrajih z večjim deležem brezposelnih in ostalih neaktivnih ter slabšo izobrazbeno sestavo je torej udeležba v povprečju nižja kot v volilnih okrajih z manjšim deležem brezposelnih in ostalih neaktivnih ter boljšo izobrazbeno sestavo. Ti rezultati se bolj ali manj ujemajo z ugotovitvami iz drugih raziskav (Wolfinger in Rosenstone 1980; Blais 2000), kjer sta stopnja brezposelnosti in izobrazba ena od najpomembnejših dejavnikov udeležbe. Zanimiva je močna povezanost 


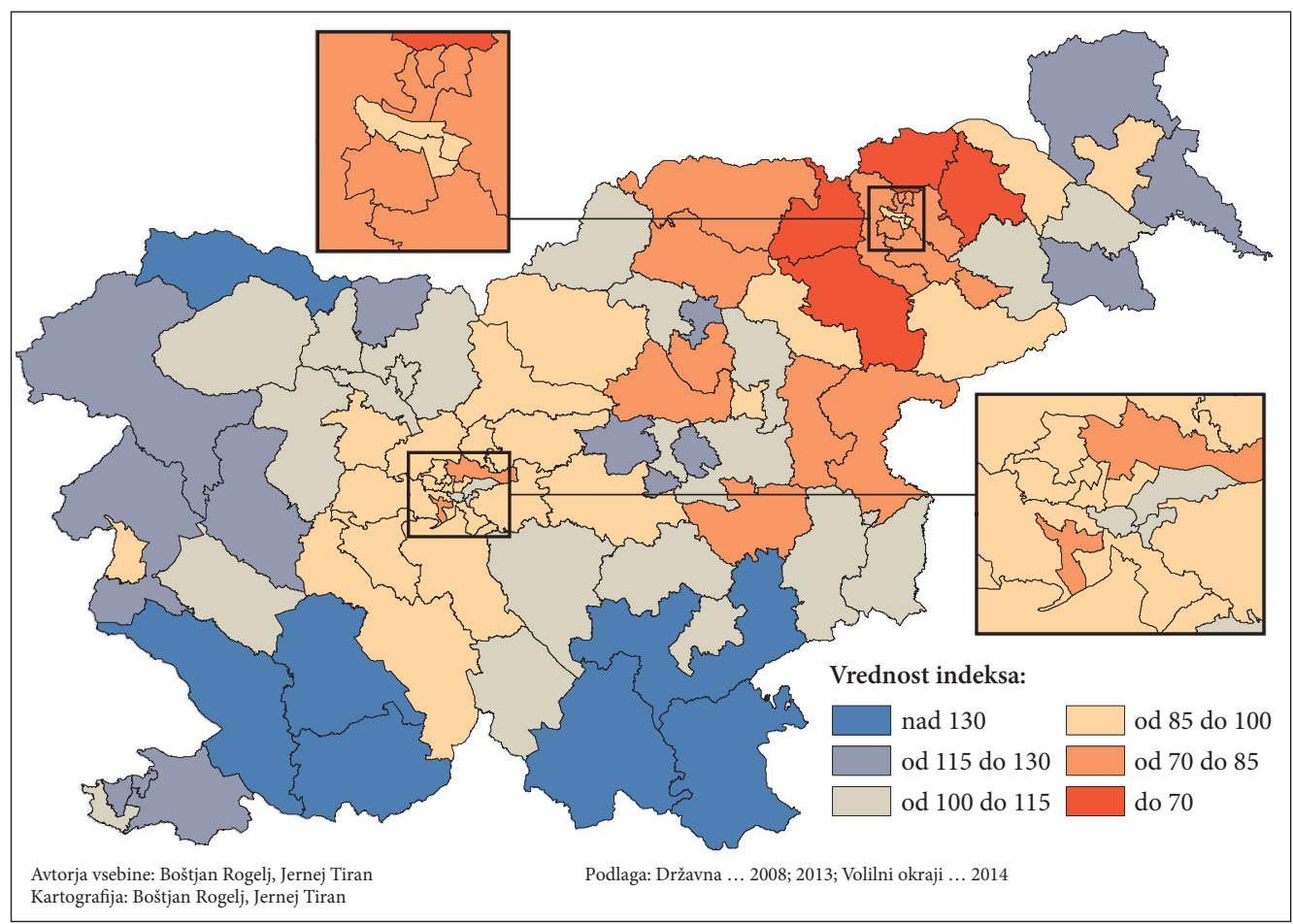

Slika 5: Indeks sprememb volilne udeležbe med obdobjema 1992-2000 in 2004-2014 (viri za izračun: Statistični letopis... 1992; Volilna statistika ... 1996; Državnozborske volitve ... 2000; 2004; Volitve ... 2008; Predčasne volitve... 2011; 2014).

udeležbe s kategorijo ostalih neaktivnih, ki pa ni nepričakovana, saj jo sestavljajo skupine prebivalcev, ki so po drugih raziskavah (Milbrath in Goel 1977; Della Porta 2003) politično najbolj pasivne in apatične: prejemniki socialnih in drugih pomoči ter nadomestil, družinski člani zavarovancev (na primer gospodinje), prejemniki državnih pokojnin in osebe, ki delajo, vendar njihovo delo ni zabeleženo v uradni statistiki (Medmrežje 4). Udeležba je zmerno pozitivno povezana tudi $\mathrm{z}$ večjim deležem učencev, dijakov in študentov, kar bi lahko kazalo na višjo stopnjo volilne angažiranosti šolajočih se mlajših volivcev v primerjavi z nešolajočimi, a bi jo bilo treba preveriti tudi na ravni individualnih podatkov.

Naslednji, čeprav nekoliko manj pomemben dejavnik je starostna sestava prebivalstva. Zanimivo je, da višjo volilno udeležbo beležijo okraji z večjim deležem volivcev, starih od 35 do 50 let, nižjo pa okraji z večjim deležem volivcev od 50 do 64 let. Nekoliko preseneča tudi podatek, da volilna udeležba ni povezana z deležem starejših od 65 let in deležem upokojencev, po drugi strani pa izračuni kažejo neznatno, a statistično pomembno pozitivno povezanost med volilno udeležbo in deležem mladih (od 18 do 34 let). Pri interpretaciji teh rezultatov je treba biti zelo previden, saj so v popolnem nasprotju $\mathrm{z}$ rezultati nedavnih vzporednih volitev, ki so pokazali, da volilno telo večine političnih strank sestavljajo ravno volivci, starejši od 45 let, največji volilni abstinenti pa soravno mlajši volivci (Medmrežje 5).

Velika previdnost je potrebna tudi pri interpretaciji povezanosti med volilno udeležbo in sektorjem zaposlitve. Koeficienti korelacije sicer kažejo na statistično pomembno povezanost, a smo z izračuni

Slika 6: Prostorski prikaz volilne udeležbe na predčasnih volitvah v Državni zbor 2014 na ravni volišč.

\section{str. 34}




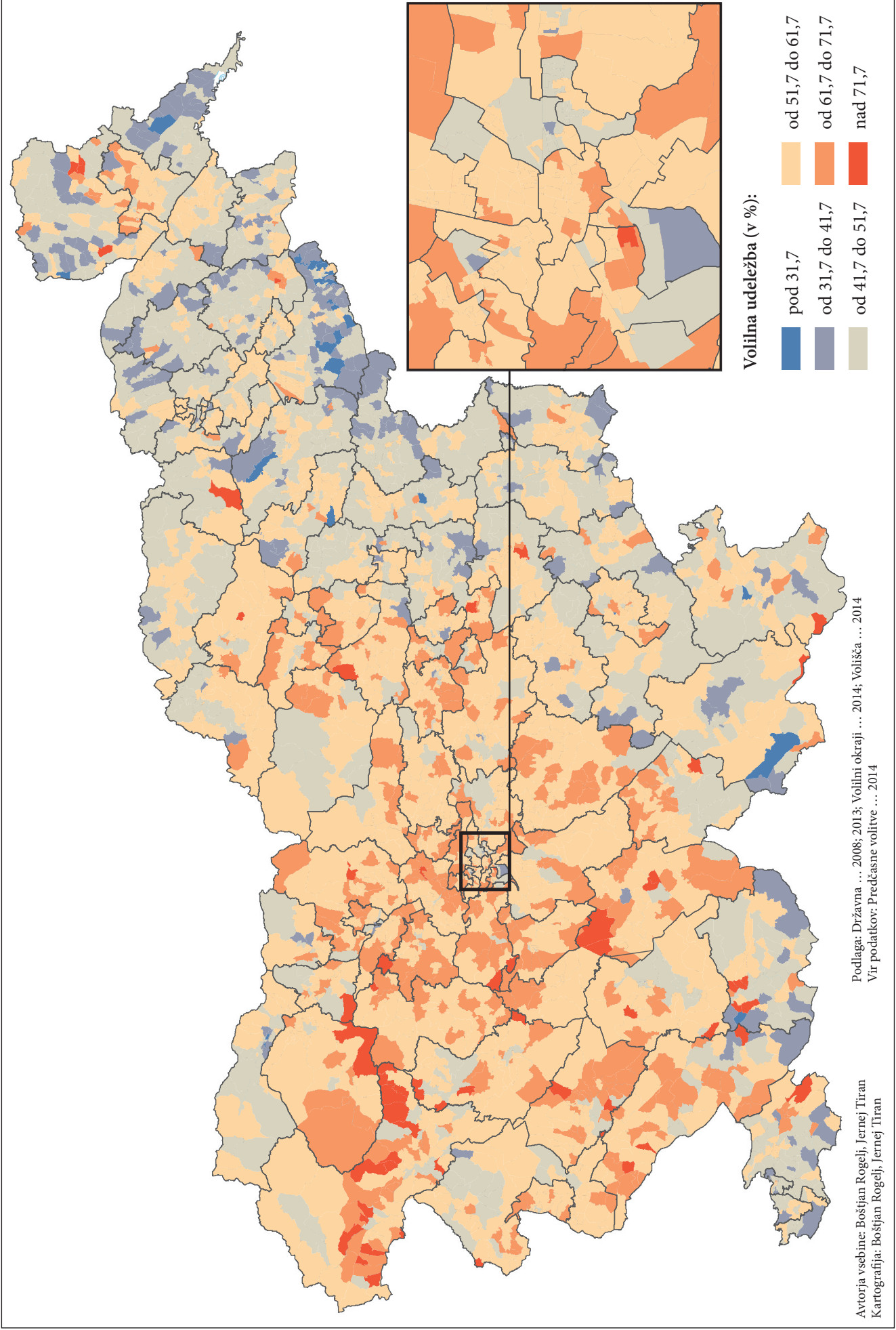


parcialnih korelacij naknadno ugotovili, da je to posledica delovanja drugih spremenljivk, zlasti izobrazbene sestave.

Prav tako se je za statistično nepomembno izkazala povezanost med volilno udeležbo in deležem priseljencev oziroma deležem prebivalcev s prvim prebivališčem bodisi v Sloveniji bodisi v tujini. Posledično lahko zavrnemo tezo o domnevni mobilizaciji »novih državljanov« (Medmrežje 2) na volitvah 2011, pri čemer pa bi jo bilo treba preveriti tudi na ravni manjših prostorskih enot in individualnih podatkov.

Preglednica 3: Pearsonovi korelacijski koeficienti med volilno udeležbo leta 2011 oziroma leta 2014 in izbranimi kazalniki.

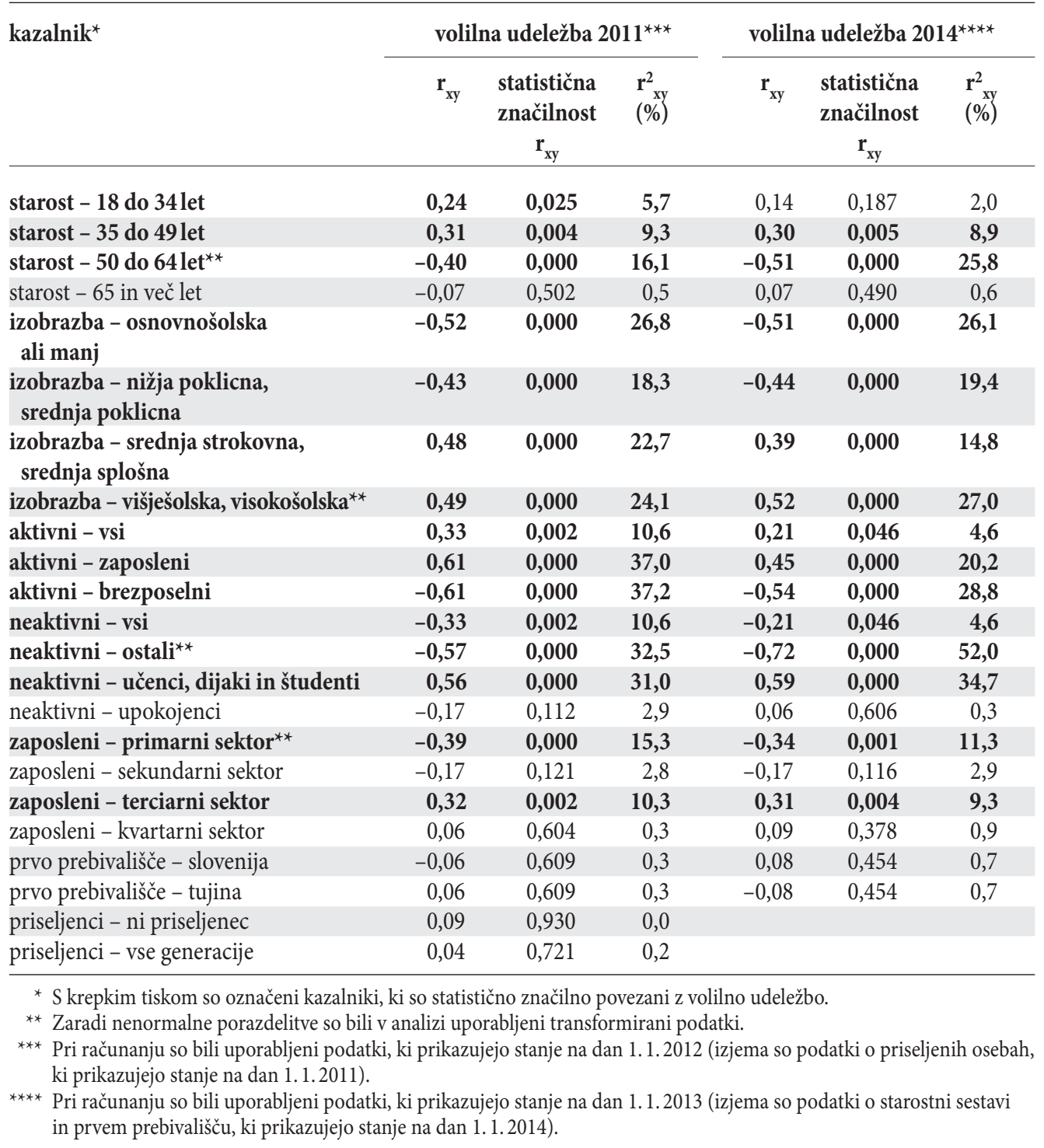


Primerjava korelacijskih koeficientov za volitve 2011 in 2014 je pokazala, da v večini primerov ni prišlo do bistvenih sprememb, vendar pa obstaja nekaj pomembnih izjem. Izpostaviti velja zlasti močnejšo povezanost udeležbe na volitvah $2014 \mathrm{z}$ deležem neaktivnih - ostalih in manjšo povezanost $\mathrm{z}$ deležema brezposelnih in zaposlenih.

$\mathrm{Z}$ enosmerno analizo variance smo nato preverili, ali se štiri skupine volilnih okrajev, oblikovane na podlagi podatkov o volilni udeležbi med letoma 2004 in 2014, med seboj statistično pomembno razlikujejo glede na izbrane kazalnike za leto 2012, ki so predhodno izkazovali najvišje vrednosti korelacijskih koeficientov. Pričakovali smo, da se bosta prva (močno podpovprečna udeležba) in zadnja skupina (močno nadpovprečna udeležba) statistično pomembno razlikovali od ostalih skupin. Rezultati so le delno potrdili naša pričakovanja. Pri veliki večini kazalnikov izstopa skupina z močno nadpovprečno udeležbo, ki se statistično pomembno razlikuje od ostalih treh skupin, medtem ko razlike med ostalimi tremi skupinami večinoma niso statistično pomembne (preglednica 4).

Skupina z močno nadpovprečno udeležbo ima zelo dobro izobrazbeno sestavo, saj je delež visokošolsko in višješolsko izobraženih izredno velik, nadpovprečen pa je tudi delež prebivalcev s srednješolsko izobrazbo. Zanjo so značilni tudi: večji delež prebivalcev, zaposlenih v terciarnem sektorju, manjši delež prebivalcev, zaposlenih $\mathrm{v}$ primarnem sektorju in nadpovprečen delež aktivnega zaposlenega prebivalstva. Skupina ima tudi nekoliko večji delež prebivalcev, starih od 35 do 49 let in nekoliko manjši delež starih od 50 do 64 let.

Nekoliko bolj kompleksne so razlike pri deležu brezposelnih in deležu ostalih neaktivnih. Pri deležu brezposelnih so statistično pomembne razlike med vsemi skupinami razen med skupinama $\mathrm{z}$ močno podpovprečno in podpovprečno udeležbo. Obratno velja za delež ostalih neaktivnih - tu obstajajo

Preglednica 4: Primerjava aritmetičnih sredin izbranih kazalnikov med skupinami volilnih okrajev na podlagi volilne udeležbe v obdobju 2004-2014.

\begin{tabular}{|c|c|c|c|c|c|c|c|}
\hline \multirow[t]{2}{*}{ kazalnik } & \multicolumn{4}{|c|}{ aritmetične sredine skupin ${ }^{\star *}$} & \multirow[b]{2}{*}{ 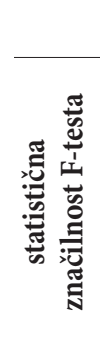 } & \multirow[b]{2}{*}{ 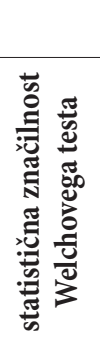 } & \multirow[b]{2}{*}{ 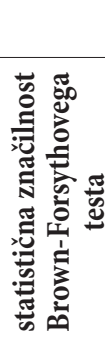 } \\
\hline & 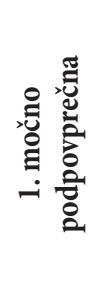 & 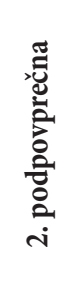 & 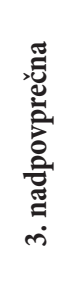 & 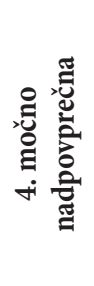 & & & \\
\hline starost -35 do 49 let & 26,1 & 26,1 & 25,9 & 27,5 & 0,001 & 0,001 & 0,001 \\
\hline starost -50 do 64 let ${ }^{*}$ & 26,6 & 26,7 & 26,1 & 24,1 & 0,000 & 0,000 & 0,000 \\
\hline izobrazba - osnovnošolska ali manj & 28,9 & 26,0 & 25,3 & 20,3 & 0,000 & 0,000 & 0,000 \\
\hline izobrazba - nižja poklicna, srednja poklicna & 24,4 & 24,3 & 23,2 & 19,7 & 0,000 & 0,000 & 0,000 \\
\hline izobrazba - srednja strokovna, srednja splošna & 30,6 & 31,6 & 31,4 & 34,4 & 0,000 & 0,000 & 0,000 \\
\hline izobrazba - višješolska, visokošolska* & 16,1 & 18,1 & 20,1 & 25,6 & 0,000 & 0,000 & 0,000 \\
\hline aktivni - brezposelni & 7,5 & 7,5 & 6,2 & 5,0 & 0,000 & 0,000 & 0,000 \\
\hline aktivni - zaposleni & 45,6 & 46,7 & 47,4 & 50,1 & 0,000 & 0,000 & 0,000 \\
\hline neaktivni - ostali* & 7,3 & 6,1 & 5,2 & 5,1 & 0,000 & 0,000 & 0,000 \\
\hline neaktivni - učenci, dijaki in študenti & 6,5 & 7,0 & 7,5 & 7,8 & 0,000 & 0,000 & 0,000 \\
\hline zaposleni - primarni sektor* & 4,0 & 3,2 & 2,5 & 1,5 & 0,020 & 0,016 & 0,032 \\
\hline zaposleni - terciarni sektor & 41,7 & 39,1 & 39,3 & 49,2 & 0,001 & 0,001 & 0,001 \\
\hline
\end{tabular}

* Zaradi nenormalne porazdelitve so bili v analizi uporabljeni transformirani podatki.

** Odebeljena pisava pomeni, da se skupina po izbranem kazalniku statistično pomembno razlikuje od vseh ostalih skupin. 
Preglednica 5: Osnovne značilnosti štirih regresijskih modelov za napovedovanje udeležbe na volitvah 2011.

\begin{tabular}{|c|c|c|c|c|c|c|}
\hline model & $\mathrm{R}^{2}$ & $\mathrm{~F}$ & vključene spremenljivke & B & SE (B) & $\beta$ \\
\hline \multirow[t]{2}{*}{1} & 0,372 & $50,955^{\star}$ & konstanta & 77,49 & 1,73 & \\
\hline & & & aktivni - brezposelni (2012) & $-1,82$ & 0,26 & $-0,61^{*}$ \\
\hline \multirow[t]{3}{*}{2} & 0,547 & $51,277^{\star}$ & konstanta & 94,72 & 3,35 & \\
\hline & & & aktivni - brezposelni (2012) & $-1,47$ & 0,23 & $-0,49^{*}$ \\
\hline & & & neaktivni - ostali (2012) (T) & $-11,26$ & 1,97 & $-0,43^{*}$ \\
\hline \multirow[t]{4}{*}{3} & 0,643 & $50,373^{*}$ & konstanta & 74,77 & 5,16 & \\
\hline & & & aktivni - brezposelni (2012) & $-1,19$ & 0,21 & $-0,40^{*}$ \\
\hline & & & neaktivni - ostali (2012) (T) & $-10,27$ & 1,77 & $-0,40^{*}$ \\
\hline & & & višješolska in visokošolska izobrazba (2012) (T) & 5,56 & 1,17 & $0,33^{*}$ \\
\hline \multirow[t]{5}{*}{4} & 0,687 & $45,517^{\star}$ & konstanta & 53,34 & 7,93 & \\
\hline & & & neaktivni - ostali (2012) (T) & $-10,08$ & 1,67 & $-0,39^{*}$ \\
\hline & & & višješolska in visokošolska izobrazba (2012) (T) & 5,99 & 1,11 & $0,35^{*}$ \\
\hline & & & aktivni - brezposelni (2012) & $-0,84$ & 0,22 & $-0,28^{*}$ \\
\hline & & & starostna skupina 50-64 let (2012) (T) & 452,50 & 132,30 & $0,24^{*}$ \\
\hline
\end{tabular}

* statistična značilnost $<0,001$

(T): transformirane spremenljivke

Preglednica 6: Osnovne značilnosti štirih regresijskih modelov za napovedovanje udeležbe na volitvah 2014.

\begin{tabular}{|c|c|c|c|c|c|c|}
\hline model & $\mathrm{R}^{2}$ & $\mathrm{~F}$ & vključene spremenljivke & B & SE (B) & $\beta$ \\
\hline \multirow[t]{2}{*}{1} & 0,520 & $93,32^{*}$ & konstanta & 66,39 & 1,56 & \\
\hline & & & neaktivni - ostali (2013) (T) & $-2,18$ & 0,23 & $-0,72^{*}$ \\
\hline \multirow[t]{3}{*}{2} & 0,661 & $82,89^{*}$ & konstanta & 37,26 & 5,08 & \\
\hline & & & neaktivni ostali (2013) (T) & $-1,89$ & 0,20 & $-0,63^{*}$ \\
\hline & & & starostna skupina 50-64let (2014) (T) & 715,38 & 120,45 & $0,39^{*}$ \\
\hline \multirow[t]{4}{*}{3} & 0,725 & $73,94^{*}$ & konstanta & 25,82 & 5,27 & \\
\hline & & & neaktivni ostali (2013) (T) & $-1,62$ & 0,19 & $-0,54^{*}$ \\
\hline & & & starostna skupina 50-64 let (2014) (T) & 626,59 & 110,90 & $0,34^{*}$ \\
\hline & & & višješolska in visokošolska izobrazba (2013)(T) & 4,35 & 0,98 & $0,28^{*}$ \\
\hline \multirow[t]{5}{*}{4} & 0,740 & $58,94^{*}$ & konstanta & 33,34 & 6,25 & \\
\hline & & & neaktivni ostali (2013) (T) & $-1,54$ & 0,19 & $-0,51^{*}$ \\
\hline & & & starostna skupina 50-64 let (2014) (T) & 514,77 & 120,61 & $0,28^{*}$ \\
\hline & & & višješolska in visokošolska izobrazba (2013) (T) & 4,04 & 0,97 & $0,26^{*}$ \\
\hline & & & aktivni - brezposelni 2013 & $-0,43$ & 0,20 & $-0,14^{*}$ \\
\hline
\end{tabular}

* statistična značilnost $<0,001$

(T): transformirane spremenljivke 
pomembne razlike med vsemi skupinami razen med skupinama z močno nadpovprečno in nadpovprečno udeležbo, ki imata nižje deleže te kategorije prebivalstva kot prvi dve skupini.

$\mathrm{Na}$ koncu smo izvedli še multiplo linearno regresijsko analizo. Vanjo smo vključili izbrane kazalnike z najvišjimi stopnjami korelacije z volilno udeležbo. Preliminarni poizkusi regresijske analize so pokazali, da nekatere kazalnike, ki so statistično značilno povezani z udeležbo, ni smiselno vključiti v model, saj niso prispevali k njegovemu izboljšanju ali pa so izkazovali previsoko stopnjo multikolinearnosti z že vključenimi kazalniki.

S pomočjo metode postopnega vključevanja (stepwise) so bili izdelani štirje različni modeli za napovedovanje udeležbe na volitvah 2011, ki temeljijo na kazalnikih za leto 2012. Za najboljšega se je izkazal model s štirimi kazalniki, ki skupaj pojasnijo več kot dve tretjini variance odvisne spremenljivke $\left(\mathrm{R}^{2}=0,687\right)$. V zadnjem modelu se za najpomembnejšega presenetljivo izkaže kazalnik ostalih neaktivnih prebival$\operatorname{cev}(\beta=-0,39)$; čeprav je na prvi stopnji oblikovanja modela najvplivnejši kazalnik delež brezposelnih $(\beta=-0,61)$, se njegov pomen z vključevanjem novih spremenljivk zaradi kolinearnosti zmanjšuje (preglednica 5).

Enak postopek smo uporabili za izdelavo štirih različnih modelov za napovedovanje volilne udeležbe leta 2014 (modeli temeljijo na kazalnikih za leti 2013 in 2014). Tudi v tem primeru se kot najvplivnejši kazalnik v zadnjem izmed modelov izkaže delež neaktivnih - ostalih $(\beta=-0,51)$, ki že v prvem od modelov pojasni več kot polovico variance odvisne spremenljivke, delež brezposelnosti pa se vključi šele $\mathrm{v}$ četrtega od modelov in komajda še bistveno prispeva $\mathrm{k}$ statistični značilnosti njegove izboljšave v primerjavi s tretjim. To je morda tudi posledica večje volilne abstinence zaposlenega prebivalstva, ki so se zaradi časa dopustov v manjši meri udeležili volitev. Nekoliko presenetljivo se je kot drugi najpomembnejši dejavnik izkazal delež prebivalcev v starostni skupini od 50 do 64 let. S končnim

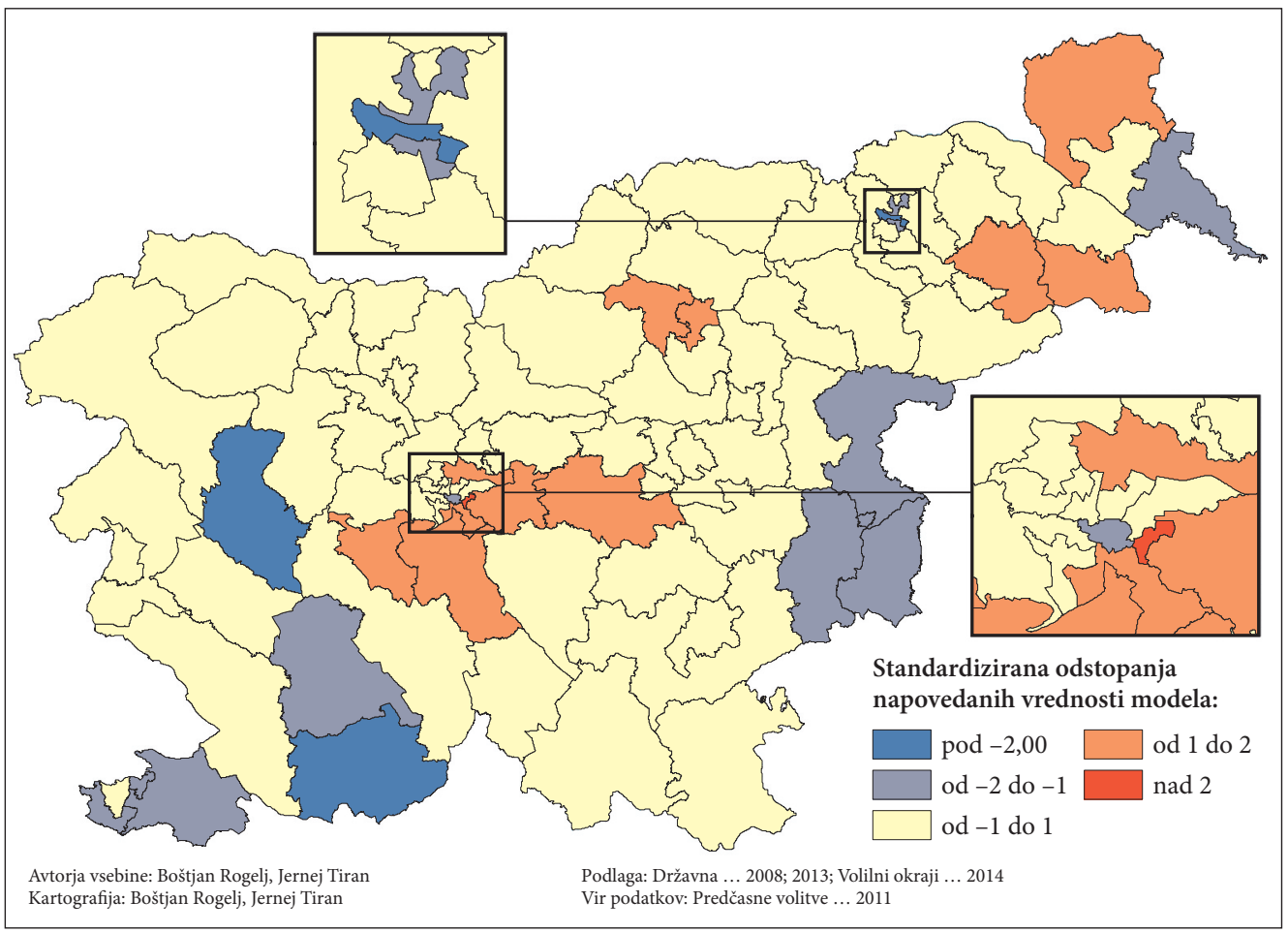

Slika 7: Standardizirane napake napovedi regresijskega modela - predčasne volitve v Državni zbor leta 2011. 
modelom smo uspeli pojasniti še večji delež variance udeležbe kot za volitve 2011, in sicer 74 \% (preglednica 6).

Sliki 7 in 8 prikazujeta standardizirane napake napovedi končnih regresijskih modelov dejanske udeležbe po volilnih okrajih, pri čemer smo izpostavili območja, kjer je razlika med napovedano in dejansko udeležbo večja od enega standardnega odklona. $V$ teh okrajih so na volilno udeležbo pomembno vplivali dejavniki, ki jih nismo vključili v model (v okrajih z negativnimi vrednostmi smo udeležbo precenili, v okrajih s pozitivnimi vrednostmi pa podcenili).

Model za leto 2011 (slika 7) je močno podcenil udeležbo v nekaterih volilnih okrajih v Ljubljani in okolici, v obeh velenjskih volilnih okrajih ter nekaterih volilnih okrajih v severovzhodni Sloveniji (Murska Sobota I, Ptuj I in Ormož). Večjo udeležbo v Ljubljani in okolici od pričakovane si lahko razlagamo z nastopom ljubljanskega župana Zorana Jankovića in njegove stranke Pozitivna Slovenija na državnozborskih volitvah. Izrazito podcenjena napoved v okraju Ljubljana Moste-Polje II (med drugim obsega tudi blokovski soseski Štepanjsko naselje in Fužine) ter obeh velenjskih okrajih bi lahko kazala na to, da je v posameznih okoljih dejansko prišlo do določene mobilizacije do tedaj politično manj angažiranih volivcev. Razlago podcenjenih napovedi leta 2014 (slika 8) je težje spraviti na en skupni imenovalec. Volilni okraji, kjer je bila volilna udeležba večja od napovedi modela, so namreč prostorsko razpršeni ter z vidika demografske in družbenogospodarske sestave veliko bolj heterogeni. Razloge za višjo udeležbo gre v teh okrajih najverjetneje iskati v specifičnih političnih dejavnikih (večja tekmovalnost, mobilizacije volivcev, večja organizacijska usrediščenost posameznih strank v določenih okoljih in podobno).

Na drugi strani pa imamo relativno veliko skupino okrajev, pri katerih so napovedi obeh modelov močno precenjene. $\mathrm{V}$ to skupino sodita oba koprska, ilirskobistriški, postojnski in idrijski okraj v zahodni

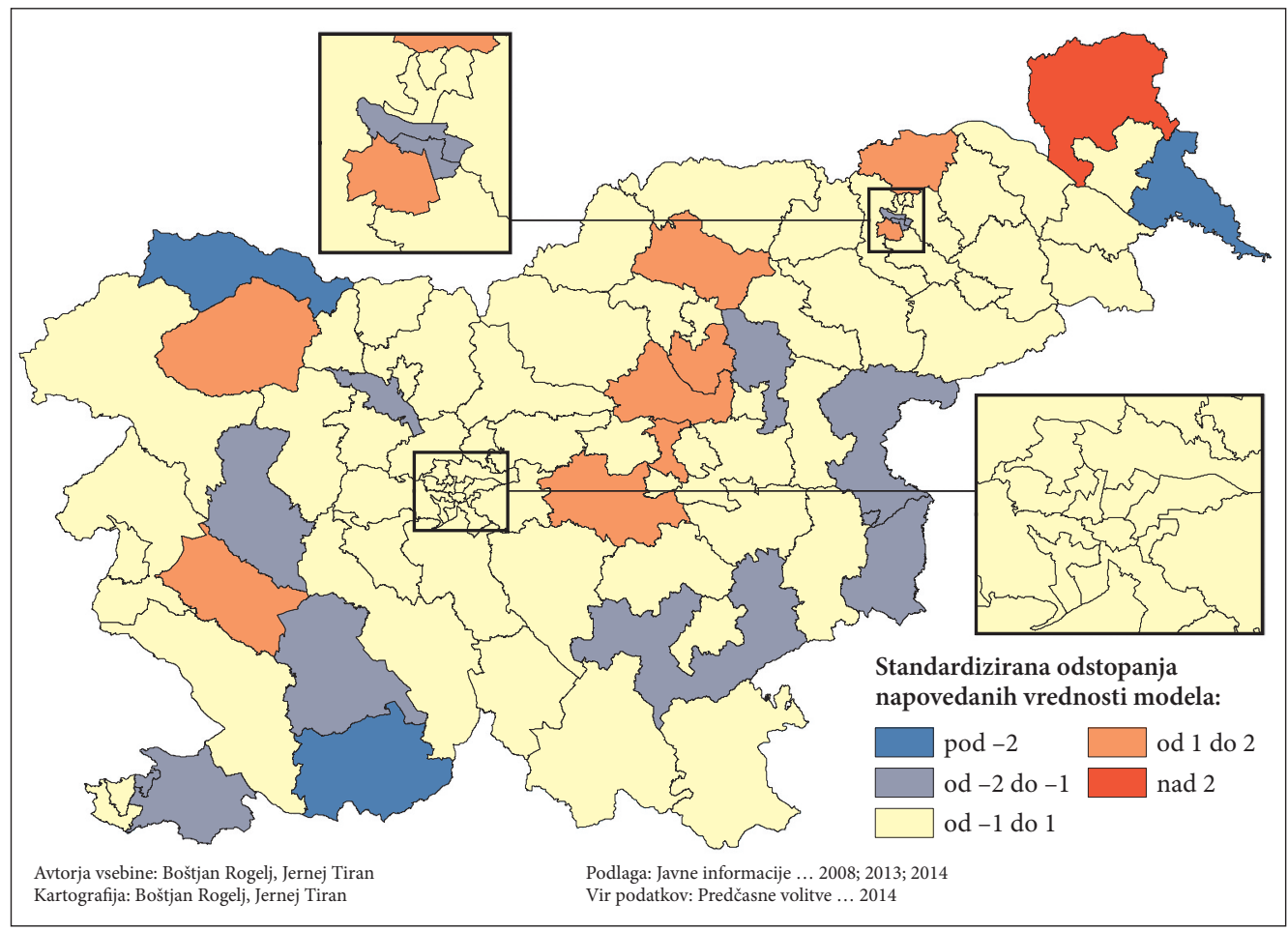

Slika 8: Standardizirane napake napovedi regresijskega modela - predčasne volitve v Državni zbor leta 2014. 
Sloveniji ter okraji Lendava, Šmarje pri Jelšah, Brežice in dva mariborska okraja v vzhodni Sloveniji. V okraju Lendava je bila volilna udeležba leta 2014 samo 38,4-odstotna in že na tretjih volitvah zapored najnižja v državi. Stalna (pre)nizka volilna udeležba v teh okrajih najverjetneje kaže na visoko stopnjo nezadovoljstva, razočaranja in apatije tamkajšnjega prebivalstva, kar nakazuje na aktiven pomen prostora kot dejavnika volilne udeležbe. Tako se nizka raven politične participacije v procesu poenotenja stališč in vedenjskih vzorcev prenaša tudi na tiste državljane, ki bi se glede na svoje družbene in demografske značilnosti volitev sicer načeloma udeležili.

\section{Sklep}

Naraščajoča volilna neudeležba v modernih družbah je pojav, za katerega kljub vedno večjemu številu raziskav še nimamo pravega pojasnila. Podobno velja tudi za Slovenijo, kjer je volilna udeležba od volitev leta 1992 do danes močno upadla in se močno približala »kritični« meji petdesetih odstotkov. Z analizo, ki smo jo napravili na podlagi volilnih okrajev na nizu volitev v Državni zbor od leta 1992 naprej, smo ugotovili, da so v Sloveniji prostorske razlike v volilni udeležbi sicer prisotne, a se v nasprotju z nekaterimi pričakovanji v času niso povečale. Spremenila pa se je prostorska struktura volilne udeležbe, saj je polarizacijo vzhod-zahod iz devetdesetih let prejšnjega stoletja zamenjala polarizacija osrednja-preostala Slovenija, kar je v glavnem posledica nadpovprečnega zmanjšanja udeležbe v jugozahodni Sloveniji in podpovprečnega zmanjšanja udeležbe v večjem delu vzhodne Slovenije.

V prispevku smo skušali odgovoriti tudi na vprašanje, katere so tiste demografske in družbenogeografske značilnosti volilnih okrajev, ki so najmočneje povezane z volilno udeležbo. Rezultati korelacijske analize in enosmerne analize variance so bili dokaj pričakovani, saj sta se kot najpomembnejša dejavnika udeležbe na volitvah leta 2011 in 2014 pokazala izobrazbena sestava in aktivnost. Volilni okraji z boljšo izobrazbeno sestavo in nižjim deležem brezposelnosti in ostalih neaktivnih imajo v povprečju višjo udeležbo od okrajev s slabšo izobrazbeno sestavo in večjim deležem brezposelnosti. Naslednja, a že nekoliko manj pomembna dejavnika sta starostna sestava, pri kateri pa je potrebna velika previdnosti pri interpretaciji, in zaposlitvena sestava (zlasti deleža zaposlenih v primarnem in terciarnem sektorju), medtem ko se delež priseljencev ni izkazal kot statistično pomemben dejavnik. Izvedli smo tudi multiplo linearno regresijsko analizo, $s$ katero smo uspeli pojasniti zelo velik delež variabilnosti volilne udeležbe, a so se rezultati za volitve leta 2011 in leta 2014 zelo razlikovali, zlasti po neznatnem vplivu stopnje brezposelnosti na volitvah leta 2014, kar je morda posledica večje volilne abstinence zaposlenega prebivalstva, ki se je zaradi časa dopustov v manjši meri udeležil volitev, kot sicer. Rezultati regresijske analize obenem odpirajo vprašanje, koliko na udeležbo vpliva specifičen geografski prostor, milje. Za nekatere okraje so namreč značilna precejšnja odstopanja med dejansko in $\mathrm{z}$ regresijskim modelom napovedano udeležbo.

Ob tem velja opozoriti, da so nekateri volilni okraji demografsko in družbenogospodarsko dokaj heterogeni, zato moči posameznih dejavnikov ni mogoče aplicirati na raven posameznikov. Zato bi bila v prihodnje več kot smiselna kombinirana analiza na ravni individualnih, javnomnenjskih podatkov (ki žal trenutno še ne obstaja) in agregiranih podatkov na ravni volišč ali vsaj občin. Pri tem pa bi morali premostiti nekatere težave glede neujemanja meja in pridobivanja podatkov, med katere bi veljalo vključiti tudi podatke o dohodkih oziroma povprečne bruto plače ali podatke o deležu zaposlenih $v$ javnem sektorju. Zanimivo bi bilo primerjati tudi udeležbo na volitvah v Državni zbor z udeležbo na ostalih volitvah (predsedniških, lokalnih in v evropski parlament) in referendumih ter uspešnostjo posameznih političnih strank. Upamo, da bo ta raziskava pripomogla k večjemu zanimanju za tematiko ne le med geografi, ampak tudi širše. 


\section{Viri in literatura}

Agnew, J. A. 1987: Place and politics. The Geographical Mediation of State and Society. Boston.

Blais, A. 2000: To vote or not to vote? The Merits and Limits of Rational Choice. Pittsburgh.

Blais, A. 2006: What affects voter turnout? Annual Review of Political Science 9. DOI: 10.1146/ annurev.polisci.9.070204.105121

Brezovšek, M. 2002: Volitve in politično predstavništvo. Parlamentarne volitve 2000. Ljubljana.

Cox, K. R. 1968: Suburbia and voting behaviour in the London metropolitan area. Annals of the Association of American Geographers 58. DOI: 10.1111/j.1467-8306.1968.tb01639.x

Della Porta, D. 2003: Temelji politične znanosti. Ljubljana.

Delwit, P. 2013: The end of voters in Europe? Electoral turnout in Europe since WWII. Open Journal of Political Science 3-1. DOI: 10.4236/ojps.2013.31007

Državljani Republike Slovenije, stari 18 ali več let, s stalnim prebivališčem v Sloveniji po generaciji priseljenca, volilni okraji, Slovenija, 1. januar 2011. Statistični urad Republike Slovenije. Ljubljana, 2011.

Državljani Republike Slovenije, stari 18 ali več let, s stalnim prebivališčem v Sloveniji po starosti in spolu, volilni okraji, Slovenija, 1. januar 2012. Statistični urad Republike Slovenije. Ljubljana, 2012a.

Državljani Republike Slovenije, stari 18 ali več let, s stalnim prebivališčem v Sloveniji po spolu in doseženi izobrazbi, volilni okraji, Slovenija, 1. januar 2012. Statistični urad Republike Slovenije. Ljubljana, 2012 b.

Državljani Republike Slovenije, stari 18 ali več let, s stalnim prebivališčem v Sloveniji po spolu in statusu aktivnosti, volilni okraji, Slovenija, 1. januar 2012. Statistični urad Republike Slovenije. Ljubljana, 2012c.

Državljani Republike Slovenije, stari 18 ali več let, s stalnim prebivališčem v Sloveniji po spolu in prvem prebivališču, volilni okraji, Slovenija, 1. januar 2012. Statistični urad Republike Slovenije. Ljubljana, 2012d.

Državljani Republike Slovenije, stari 18 ali več let, s stalnim prebivališčem v Sloveniji po spolu in doseženi izobrazbi, volilni okraji, Slovenija, 1. januar 2013. Statistični urad Republike Slovenije. Ljubljana, 2013a.

Državljani Republike Slovenije, stari 18 ali več let, s stalnim prebivališčem v Sloveniji po spolu in statusu aktivnosti, volilni okraji, Slovenija, 1. januar 2013. Statistični urad Republike Slovenije. Ljubljana, 2013 b.

Državljani Republike Slovenije, stari 18 ali več let, s stalnim prebivališčem v Sloveniji po starosti in spolu, volilni okraji, Slovenija, 1. januar 2014. Statistični urad Republike Slovenije. Ljubljana, 2014a.

Državljani Republike Slovenije, stari 18 ali več let, s stalnim prebivališčem v Sloveniji po spolu in prvem prebivališču, volilni okraji, Slovenija, 1. januar 2014. Statistični urad Republike Slovenije. Ljubljana, 2014 b.

Državna pregledna karta 1:1.000.000. Geodetska uprava Republike Slovenije. Ljubljana, 2008.

Državna pregledna karta 1:250.000. Geodetska uprava Republike Slovenije. Ljubljana, 2013.

Državnozborske volitve 2000, Slovenija. Rezultati raziskovanj 750. Statistični urad Republike Slovenije. Ljubljana, 2000.

Državnozborske volitve, Slovenija, 3.10.2004. Rezultati raziskovanj 818. Statistični urad Republike Slovenije. Ljubljana, 2004.

Fink-Hafner, D. 1993: Uspešnost utrjevanja demokracije na Slovenskem: nekateri kazalci. Problemi konsolidacije demokracije, Politološki dnevi Ankaran '93. Ljubljana.

Kropivnik, S. 1998: Slovenski volivci v geografskem, družbenem in ideološkem prostoru. Ljubljana.

Kropivnik, S., Vrhovac, S. 2012: Pojavi politične patologije v evropskih novih demokracijah. Teorija in praksa 49, 4-5. Ljubljana.

Le Duc, L., Pammet, J.H. 2003: Elections and Participation: The Meaning of the Turnout Decline. Medmrežje: http://www.cpsa-acsp.ca/paper-2003/leduc.pdf (16.8. 2014).

Medmrežje 1: http://www.rtvslo.si/volitve-v-dz/jansa-letos-je-bogastvo-vplivalo-na-volitve/92641 (15.8.2014).

Medmrežje 2: http://www.sds.si/news/10328 (15.8.2014).

Medmrežje 3: http://www.sds.si/news/13177 (15.8.2014).

Medmrežje 4: http://www.stat.si/popis2011/DefAktivnost.aspx (16.9.2014). 
Medmrežje 5: http://www.rtvslo.si/dz-volitve-2014/sds-u-sta-volivce-prevzela-tudi-miro-cerar-in-zdruzena-levica/342089 (21.10.2014).

Milbrath, L. W., Goel, M. L. 1977: Political Participation: How and Why Do People Get Involved in Politics? Chicago.

Niemi, R. G., Weisberg, H. F. (ur.) 2001: Controversies in Voting Behavior. Washington.

Pattie, C., Johnston, R. 1998: Voter turnout at the British General Election of 1992: Rational choice, social standing or political efficacy? European Journal of Political Research 33. DOI: 10.1111/ 1475-6765.00383

Predčasne volitve v državni zbor 2011. Državna volilna komisija. Ljubljana, 2011. Medmrežje: http://www.dvk-rs.si/arhivi/dz2011/ (15.8.2014).

Predčasne volitve v Državni zbor 2014. Državna volilna komisija. Ljubljana, 2014. Medmrežje: http://www.dvk-rs.si/arhivi/dz2014/ (15.8.2014).

Rebernik, D. 2013: Social areas in Ljubljana. Dela 39. Ljubljana. DOI: 10.4312/dela.39.1.5-26

Rogelj, B. 2012: Ureditev volilnih enot v državnozborskem volilnem sistemu. Dela 37. Ljubljana. DOI: 10.4312/dela.37.6.107-128

Sigelman, L., Roeder, P. W., Jewell, M. E., Baer, M. A. 1985: Voting and nonvoting: A multi-election perspective. American Journal of Political Science 29-4. DOI: 10.2307/2111179

Statistični letopis Republike Slovenije 1992. Statistični urad Republike Slovenije. Ljubljana, 1992. Medmrežje: http://www.stat.si/letopis/index_vsebina.asp?leto=1992\&jezik=si (5.6.2014).

Tiran, J. 2011: Settlement area type as a factor of electoral behaviour in Slovenia. Hrvatski geografski glasnik 73-1. Zagreb.

Volilna statistika in referendumi: Volitve v Državni zbor, Republika Slovenija, 10.11.1996. Statistične informacije 332. Statistični urad Republike Slovenije. Ljubljana, 1996.

Volilni okraji (stanje na dan 13.7.2014). Geodetska uprava Republike Slovenije. Ljubljana, 2014.

Volišča za državnozborske volitve (stanje na dan 13.7.2014). Geodetska uprava Republike Slovenije. Ljubljana, 2014.

Volitve v Državni zbor 2008. Državna volilna komisija. Ljubljana, 2008. Medmrežje: http://www.dvk-rs.si/ arhivi/dz2008/ (15.9.2009).

Wattenberg, M. P. 2002: Where have all the voters gone? Cambridge.

Wesley, J. 2012: Voter turnout in Manitoba. An ecological analysis. Canadian Political Science Review 6, 2-3.

Wolfinger, R. E., Rosenstone, S. J. 1980: Who Votes? New Haven.

Zaposleni državljani Republike Slovenije, stari 18 ali več let, s stalnim prebivališčem v Sloveniji po spolu in sektorju dejavnosti, volilni okraji, Slovenija, 1. januar 2012. Statistični urad Republike Slovenije. Ljubljana, 2012

Zaposleni državljani Republike Slovenije, stari 18 ali več let, s stalnim prebivališčem v Sloveniji po spolu in sektorju dejavnosti, volilni okraji, Slovenija, 1. januar 2013. Statistični urad Republike Slovenije. Ljubljana, 2013.

\section{Summary: Geographical analysis of voter turnout in Slovenia} (translated by Živa Malovrh)

The article presents the geographical analysis of the voter turnout in the Slovenian parliamentary elections between 1992 and 2014. The question was whether noticeable spatial differences exist in the voter turnout in Slovenia and which demographic and socio-economic factors have the greatest effect on voter turnout. A spatial-ecological approach on the level of electoral districts was used to determine the key characteristics of voter turnout and different multivariate statistical methods were implemented in order to reveal its most important factors. Slovenia is experiencing a trend of decreasing voter turnout, 
which is also typical of other modern societies and therefore an increasingly more common topic of expert and political discussions and scientific research.

By comparing the variation coefficients and the Pearson correlation coefficients it was determined that the spatial differences in voter turnout did not increase among the electoral districts or the turnout saw an even decrease throughout the entire country. However, the spatial structure of the turnout has changed to some degree, as the east-west polarization from the 1990s shifted in the past decade towards a polarization between central Slovenia and the rest of the country. This is the consequence of an above-average decrease of voter turnout in south-west Slovenia and a below-average decrease in the greater part of eastern Slovenia. The voter turnout results for the 2014 elections were illustrated with maps at the voting poll level: the aim of this was to determine the scope of the differences in voter turnout within individual electoral districts, especially with regards to the urbanization level. We concluded that most of the electoral districts did not express major differences between the towns and their suburban and countryside hinterlands. However, noticeable differences were noted within some larger towns, especially in Ljubljana, where the spatial structure of the voter turnout corresponds closely to the socio-geographical structure.

The correlation analysis and one-way variance analysis indicated that the electoral districts with a superior educational structure and a lower unemployment level, and fewer inactive inhabitants have a higher voter turnout on average than districts with a poorer educational structure, a higher unemployment level, and more inactive inhabitants. The correlation between voter turnout and the category of inactive inhabitants is especially interesting, but not unexpected; it consists of groups of inhabitants that most foreign research has shown are the most passive and lethargic: recipients of social security and other forms of assistance and compensation, insurants' family members (for example, housewives), state pension recipients, and people with employment whose work is not recorded in the official statistics.

Finally, a multiple linear regression analysis was performed. Using the stepwise method, the selected indicators were sufficient to explain the extremely large, more than two-third share of voter turnout variance; however, the results between the 2011 and 2014 varied from one another, especially with regard to the slight effect of the unemployment level on the 2014 election. This could be a consequence of a greater voter abstention by the employed population, which participated to a lesser extent, as the elections were held during the peak summer season, a time of vacations and summer break. We also studied the deviations between the actual and the projected turnout in the electoral districts. In some areas, these were significant, which indicates other, more specific factors. The reasons for areas where the turnout was greater than the projections lay in a more expressed competitiveness, voter mobilization, stronger voter bases of certain parties in certain environments, etc. A lower turnout than the projected one points to a high level of dissatisfaction, disappointment, and the local population's apathy. Both demonstrate the active effect of place as a factor of voter turnout. This process of viewpoints being unified and common behavioral patterns being created causes the low level of political participation to be transferred to those citizens whose social and demographic traits would otherwise prompt them to participate in an election.

It should be noted that some electoral districts are demographically and socio-economically quite heterogeneous and the strength of individual factors consequently cannot be applied to the level of the individual. For this reason, future research would benefit from a combined analysis at the levels of individuals, opinion poll data, and aggregate data at the lowest possible spatial level, including data on income or data on the share of public sector employees. Another interesting possible approach would be to compare the turnout in parliamentary elections with other elections (presidential, local, and European parliamentary elections) and referendums and the success of individual political parties. 